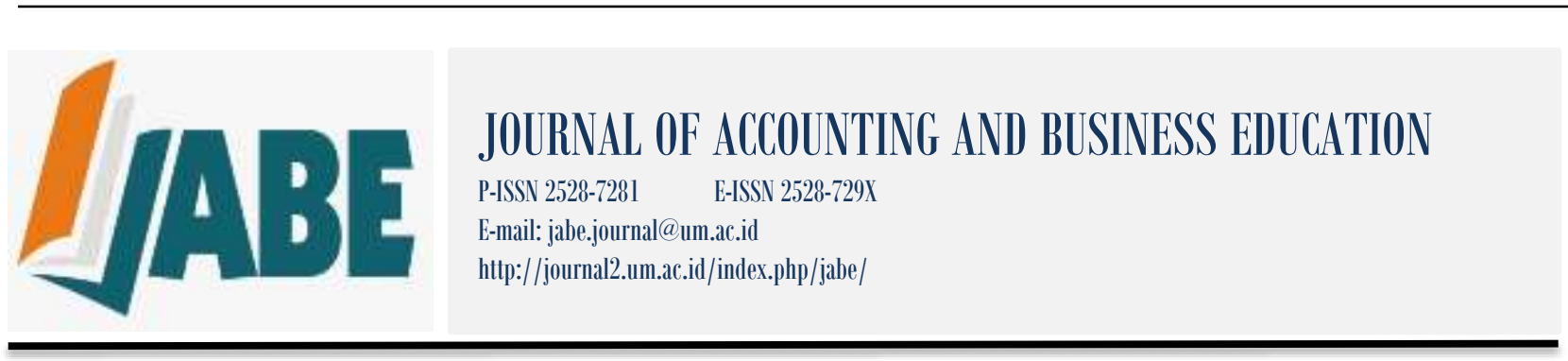

\title{
Board Diversity and Financial Performance of the Nigerian Listed Firms: A Dynamic Panel Analysis
}

\author{
Abdullahi Sani \\ Department of Accountancy, Federal Polytechnic Bali, 05, Bali, Taraba State, Nigeria \\ email:abdullahisani13@yahoo.com
}

DOI: http://dx.doi.org/10.26675/jabe.v6i1.18817

\begin{abstract}
The effect of board diversity on organisational performance has continued to be given attention by policymakers, non-governmental agencies, and academic communities. It has been established that boardroom diversity enhances the corporate boards' monitoring capacity and mitigates the agency costs, which positively influences the firms' performance. Despite the advantages of constituting diverse boards, the corporate governance framework guiding the operations of such firms does not contain any specific requirement on board diversity. Hence, empirical studies need to stress more on the relevance of boardroom diversity to firms' value in the Nigerian context. Therefore, this paper examines the effect of board diversity on financial performance of the Nigerian listed firms. The study utilised the balanced panel data of 70 firms for a period of 8 years (2012 to 2019) using a two-step system generalised method of moments (GMM) framework. This study indicates a positive and significant relationship of board gender diversity (BGD) and Foreign directors (FD), with financial performance. However, the effect of CEO financial expertise on the firms' return on assets (ROA), return on equity (ROE), and return on sales (ROS) appear positive but insignificant. Consequently, the Nigerian listed firms should attach more value to constituting a smaller board size with a considerable number of female and foreign directors to maximise their performance.
\end{abstract}

Article History

Received:

22 January 2021

Revised:

29 January 2021

Accepted:

1 February 2021

Keywords

board diversity,

financial

performance,

Nigerian listed firms,

dynamic panel

Citation: Sani, A. (2021). Board Diversity and Financial Performance of the Nigerian Listed Firms: A Dynamic

Panel Analysis. Journal of Accounting and Business Education, 6(1), 1-13.

\section{INTRODUCTION}

Board of directors and its compositions play a vital role in firms' internal governance because its decisions are directly related to various organisational outcomes. Thus, corporate boards occupy the pinnacle position in ensuring the best corporate governance practices (Gillan, 2006; Jensen, 1993). One aspect of corporate governance that has recorded heating the debates and exhibiting a growing body of literature is the boardroom diversity. The effect of board diversity on organisational performance has continued to be given attention by policymakers, non-governmental agencies, and academic communities. Drawing from the corporate governance theories, heterogeneity in terms of gender, nationality, and technical expertise enhances board monitoring and assists firms in accessing diverse resources (Adams \& Ferreira, 2009; Pfeffer \& Salancik, 2003). In particular, the board diversity as a corporate governance mechanism may control managers from embarking on inefficient investment policy and thus, limiting the scope of their underinvestment behaviour (Jensen, 1986; Li \& Zhang, 2019). In this case, improved corporate governance associated with the diversified boards may enhance the corporate disclosure and 
mitigate the agency costs, which positively influences the firms' performance (Nadeem, 2020; Vitolla, Raimo, \& Rubino, 2020).

Interestingly, the focus of this paper is on the Nigerian corporate environment because of its unique institutional structure that has a bearing on corporate governance practices. Firstly, based on the ranking released in 2020 by the world bank, Nigeria served as the largest economy in the African continent. It has a Gross Domestic Product (GDP) of $\$ 448.12$ billion in 2019, which placed the country ahead of South Africa and Egypt with an estimated GDP value of $\$ 351.432$ and $\$ 303.175$ billion respectively (World Bank, 2020). This estimate may serve as a guide to potential investors in channelling their investable funds into the region. Accordingly, Nigeria may be of keen interest to these investors given that the literature has established a link between GDP growth and the inflow of foreign direct investment to the developing economies (Iamsiraroj, 2016; Mottaleb \& Kalirajan, 2010). Therefore, a study of this nature may shed some light on the Nigerian corporate environment. Secondly, the corporate governance framework guiding companies' conduct in Nigeria does not contain a clear-cut recommendation on board diversity. Thus, suggesting the need for empirical studies to highlight the relevance of boardroom diversity in enhancing firms' performance.

Prior literature in Nigeria on this subject matter employed static estimations methods to analyse the relationship between board diversity and financial performance (Ilaboya \& Ashafoke, 2017; Ujunwa, 2012). In this context, a growing stream of the literature suggested that board diversity attributes may not be strictly exogenous variables (Kilic \& Kuzey, 2016; Wintoki, Linck, \& Netter, 2012). This conclusion implies that endogeneity effect is embedded in the board diversity-financial performance relationship. In this way, applying the static estimation methods, such as OLS and fixed effect, may yield inconsistent estimates because these techniques do not account for endogeneity (Ozkan, 2001). Hence, to generate more reliable results, this research exploited a generalised method of moments (GMM) framework to address this gap. Consequently, the empirical analysis from this paper shows that board gender diversity (BGD) and foreign directors (FD) significantly impact on financial performance of the Nigerian listed firms. The finding is robust to several measures of financial performance, such as return on assets (ROA), return on Equity (ROE), and return on sales (ROS). Thus, the evidence underscores the relevance board diversity in predicting optimum performance level of the Nigerian listed firms.

The rest part of this article proceeds as follows: the second section contains a literature review and hypotheses development, section three presents the research methodology, section four displays the empirical results and discussions, and section five contains the concluding remarks.

\section{LITERATURE REVIEW AND HYPOTHESES}

\section{Theoretical Framework}

This paper uses the agency, resource dependency, and upper echelons theories to view the nexus between firm financial performance and board diversity. In particular, the agency theory firmly stressed on the monitoring capacity of the board of directors in mitigating the potential conflicts of interests between managers and shareholders (Jensen \& Meckling, 1976). According to the agency framework, managers who are the custodians of firm resources have the incentives to pursue their personal goals at the expense of maximising the shareholders' wealth. In this way, corporate boards are constituted to monitor the managers' self-interest behaviour (Fama \& Jensen, 1983). Within the agency literature purview, studies have shown that female directors' monitoring capacity is commendable. Board meetings attendance is one of the mechanisms that the board of directors exercises its monitoring role on firms' policies. Accordingly, Adams and Ferreira (2009) found that women participation in board meetings and other committee works is higher than men. By doing so, female directors are bound to monitor firms' managers effectively. Likewise, Bart and McQueen (2013) described that women practice participative leadership style and they are more prone to asking questions and debating issues. There is also an argument that corporate boards with a substantial number of females have a higher level of disclosure and minimise earning management practices (Li, and Zhang, 2019; Nadeem, 2020). Thus, the integration of 
these attributes in the boardroom may lead to the prediction that a higher proportion of females on corporate boards might be associated with stringent monitoring, thereby enhancing firm performance. Also, prior studies argued that foreign directors bring new perspectives and expertise to the boardroom deliberations and, consequently, shaping firms' strategic decisions (Estelyi \& Nisar, 2016; Jeon \& Ryoo, 2013). Accordingly, because of their cross-country experience, foreign directors are associated with diverse skills and expertise that local directors may not possess (Estelyi, and Nisar, 2016). Similarly, these directors have a lesser connection with domestic networks and thus are more independent in discharging their board oversight functions (Min, and Chizema, 2015; Ujunwa, 2012). Their presence on board may help in reducing the information asymmetry between local firms and foreign investors. Hence, international directors are expected to enrich boards' monitoring strategy particularly if they come from countries with sound corporate governance practices (Miletkov, Poulsen, \& Wintoki, 2016).

Secondly, the resource dependency theory described how corporate board serves as a link that firms can utilise to draw valuable resources from the external environment (Pfeffer, 1973). This framework argued that the vital function of the board of directors is to provide firms with guidance, legitimacy, and expertise to enable them to attract diverse resources for their growth and development (Zahra \& Pearce, 1989). The theory hammers extensively on the board of directors' networking ability which is regarded as an essential tool for deriving recognition and legitimacy to organisations (Hillman \& Dalziel, 2003). According to Singh (2007), firms can obtain legitimacy by appointing individuals with recognition and exceptional capability on their boards to secure wider acceptance and community support. The boardroom diversity provides firms with linkages to the social and human capital by developing links with different resources and enhancing their strategic decision ability (Hillman, Cannella, \& Paetzold, 2000). This is because each board member has a unique relationship and ties with the external stakeholders. In sum, the dependency theory highlighted the relevance of board composition in attracting and co-opting the external resources required by organisations to maximise their values.

On the other hand, the upper echelons theory argued that top-level managers' cognitive ability and demographic attributes matter a lot in influencing the strategic decisions of an organisation (Hambrick \& Mason, 1984). According to this perspective, a firm's performance serves as a reflection of the cognitive power of the management team. In this regard, organisations managed by individuals with diverse educational background focus more on strategic change and are relatively more innovative (Hambrick, 2007). Within the context of this framework, a strand of literature emphasises that CEO financial expertise may explain the variation of firms' strategic policies and in turn, influencing their performance. As shown by Graham and Harvey (2001) as well as Custodio and Metzger (2014), financial expert CEOs due to their educational background adhere strictly to the prepositions of academic theories, thereby paving their ways to design better policies and may boost the firms' performance. In a nutshell, the upper echelons perspective serves as the theoretical base to view how CEO cognitive aptitude determines various organisational outcome.

\section{Board Gender Diversity and Firm Performance}

The empirical evidence on the impact of board gender on firms' performance is mixed. Some studies concluded that women have lower risk propensity and less confidence in decision making. As shown by Minguez-Vera and Martin (2011), this risk aversion of female directors may negatively affect firms' performance. Likewise, Abdullah (2014) suggested that board gender diversity leads to intra-group conflicts and a slower decision-making process, which may eventually become counter-productive to firms' performance. On the contrary, a handful of findings demonstrated that women's potentials in firm governance should not be under-rated because of their unique attributes that have a bearing on firms' strategic decisions. It has also been stated that the thinking pattern of women is superior, they take into account the viewpoints of different stakeholders, and thus, women are more likely to make a consistent and fair judgement when making decisions (Bart \& McQueen, 2013; Singh, Terjesen, \& Vinnicombe, 2008). These peculiar features of women demonstrate that gender diversity may bring a better perspective to the board, thereby enhancing corporate board decisions. In this regard, empirical studies suggested that as female directors occupy more seats on corporate boards, the financial performance of firms rises 
(Ararat, Aksu, \& Cetin, 2015; Dang, Houanti, Reddy, \& Simioni, 2020; Duppati, Rao, Matlani, Scrimgeour, \& Patnaik, 2020; Kilic \& Kuzey, 2016). Hence, this article stated the following hypothesis:

$\mathrm{H}_{1}$ : Board gender diversity is positively related to firms' financial performance.

\section{Foreign Directors and Firm performance}

There is an on-going argument that foreign directors' presence on corporate boards may also influence firms' value. In this context, some studies believed that there are high agency conflicts in firms with a higher proportion of foreign directors on their boards. It is argued that international directors have less incentives to attend board meeting sequel to the geographical distance of their home country (Masulis, Wang, \& Xie, 2012; Min \& Chizema, 2015). Consequently, the geographical distance and cross-national differences may undermine the monitoring ability of the oversee directors and thus adversely affecting firms' performance. However, Estelyi and Nisar (2016) observed that foreign directors could monitor managers vigorously due to their diverse knowledge and expertise. Thus, international directors from the countries with robust corporate governance practice than the firm's host country are relatively more active in monitoring managers (Miletkov et al., 2016). Accordingly, empirical evidence suggested that firms with many foreign board members are associated with a higher performance (Fernandez-Temprano \& TejerinaGaite, 2020; Ujunwa, 2012). Hence, this paper formulated the following hypothesis:

$\mathrm{H}_{2}$ : As the percentage of foreign directors on board increases, the firms' financial performance rises.

\section{CEO Financial Expertise and Firm Performance}

According to Hambrick (2007), a firm's performance serves as a reflection of the cognitive power of its management team. Thus, organisations managed by individuals with diverse educational backgrounds focus more on strategic change and are relatively innovative. Within this context, many studies have attempted explaining why firms behave differently, though they operate in the same economic environment, have similar size, and face equal investment opportunities (Guner, Malmendier, \& Tate, 2008; Hackbarth, 2008). These dis-similarities across firms have been attributed to the variation in managers' cognitive power. In this regard, Barney (1991) reported that the managers' cognate experience and intelligence are vital resources that determine firms' decision-making capacity. It is against this background that some studies revealed that CEOs with finance and accounting qualification are associated with better financial management strategy and are more capable of monitoring executive directors' performance (Darmadi, 2013). CEOs with Accounting and finance background are more likely to follow academically prescribed theories when designing their financial strategy (Graham and Harvey, 2001). In the same breath, the CEOs with financial expertise focus on optimum capital structure level that maximises firms' value (Custodio and Metzger, 2014). Also, Naseem, Lin, Rehman, Ahmad, and Ali (2019) argued that possession of financial education helps CEOs understand firms' financial problems, thus enabling them to act appropriately. In this way, CEOs' financial expertise enhances their ability to make better financial decisions, leading to the increased financial performance. Hence, this paper formulated the following hypothesis.

$\mathrm{H}_{3}$ : CEO financial expertise exerts a strong positive effect on firms' financial performance.

\section{METHODS}

\section{Data Source, Sampling, and Description of the Research Variables}

This research generated its data from the selected firms' annual reports and accounts covering a period of 2012-2019. firms with the missing data for three consecutive periods were dropped, and the final samples comprised of 70 listed firms operating in different Nigerian corporate sectors. These firms were purposely selected based on data availability. The research employed a panel data approach because it sampled 70 companies across different industries. The panel data technique minimises the estimation bias because the methodology controls for the heterogeneous nature of the elements under examination. 
Likewise, the panel data approach allows for more data points, which enhances the efficiency of the econometric estimates (Baltagi, 2005; Gujarati, 2003).

In this research, financial performance serves as the dependent variable, and it is measured using the accounting-based ratios, such as return on assets (ROA), return on equity (ROE), and return on sales (ROS). The accounting-based performance measures were chosen because they generally quantify managers' performance in enhancing firms' value and profitability (Kilic \& Kuzey, 2016; Ujunwa, 2012). Also, as the agency theory predicted, managers may likely to engage in maximising their utilities at the expense of the shareholders' wealth (Jensen \& Meckling, 1976). Thus, according to the theory, corporate boards are set-up to ensure that firms' managers pursue policies that can enhance the shareholders return on investment. In this way, accounting-based performance measures stand to be a more appropriate ratio in examining how boardroom diversity influences firms' performance level.

The main explanatory variables are board gender diversity (BGD), foreign directors (FD), and CEO financial expertise (CEOFE). Both agency and resource dependency theories suggested that a high degree of heterogeneity in boardroom promotes sound corporate governance and enhances firms' ability to draw valuable resources (Fama \& Jensen, 1983; Pfeffer \& Salancik, 2003). Hence, this study used the number of women and foreign directors over the total number of board members to measure BGD and FD. Moreover, the CEOFE was quantified as a dummy variable and taking the value of 1 if a CEO possess a degree in accounting and finance, otherwise 0. This measurement stemmed from the upper echelons' argument that CEO financial knowledge impacts the firms' performance level (Hambrick, 2007). Overall, this research anticipates a positive relationship between board diversity attributes and financial performance measures.

Moreover, this research employed board size (BS), total debt (TD), and firm size (FS) as control variables. BS is measured as the total numbers of board members. In this regard, a stream of the literature argued that larger board size suffers from poor coordination and slower decision-making process, which weakens sound corporate governance practices (Pillai \& Al-Malkawi, 2018; Sani, 2020; Yermack, 1996). Therefore, this article expects the board size to have a negative impact on firms' performance. Also, TD is calculated as the ratio of total debt over total assets, and it is equally assumed to be inversely related to firms' performance. This negative association between leverage and performance is consistent with studies emphasising that firms with higher profitability levels have less preference to debt financing because of the costs attached to the external funds (Sheikh \& Wang, 2013; Shyam-Sunder \& Myers, 1999). In addition, FS may also explain the variation of performance across companies due to the philosophy documented in the literature that bigger firms enjoy economies of scale (Altaf \& Shah, 2018; Muniandy \& Hillier, 2015). Therefore, this article expects a positive association between firm size and financial performance.

\section{Model Specification}

A growing stream of literature suggested that board diversity attributes may not be strictly exogenous variables (Dang et al., 2020; Kilic \& Kuzey, 2016; Wintoki et al., 2012). This conclusion implies that endogeneity effect is embedded in the board diversity-financial performance relationship. In this way, applying the static estimation methods, such as OLS and fixed effect may yield inconsistent estimates because they do not account for endogeneity bias (Ozkan, 2001). Hence, to generate more reliable results, this research exploited a generalised method of moments (GMM) framework. A GMM is a dynamic panel estimator that uses lags of the dependent variable as an instrument to deal with the endogeneity bias associated with the static estimation methods. Specifically, GMM estimator is categorised into two: difference and system GMM. The difference GMM framework uses the first differencing procedure to correct the static estimators' biases and inconsistency (Arellano \& Bond, 1991). However, simulation studies show that the difference GMM produces weak moment conditions and tends to be less efficient when applied on a series with a large panel and short time period (Bun \& Windmeijer, 2010). As a result, the system GMM estimator was developed to take care of the limitations of the first difference estimator. 
The system GMM uses the lagged differences of a dependent variable as instruments for the equation in levels. The estimator employed the moment conditions of lagged levels as instruments for the differenced equation (Blundell \& Bond, 1998). The system GMM estimate is relatively more consistent because the framework introduces more moment conditions. Thus, there are gains in precision when applied to a large panel with a short period (Arellano \& Bover, 1995). More specifically, the system GMM has two versions:one-step and two-step. The two-step GMM framework is more robust in treating heteroscedasticity and autocorrelation because this estimator utilises the firs-step errors to construct heteroscedastic-consistent standard errors (Roodman, 2009). Hence, this study used the two-step GMM framework in determining the impact of board diversity on firm performance. Accordingly, Arellano and Bond (1991) suggested some diagnostic tests to confirm the validity of GMM estimation results. These specification tests include the Arellano and Bond test with the null hypothesis that there is no secondorder serial correlation in the first differenced error-term. The other test is the Hansen statistic which assumed that GMM instruments are uncorrelated with the error term. Consequently, failure to reject the null hypotheses of these tests suggest the validity of GMM estimates. The general form of a dynamic model is given as:

$$
y_{i t}=(\partial-1) \mathrm{y}_{\mathrm{it}-1}+\beta X_{i t}+\mu_{i}+\mu_{t}+\varepsilon_{i t}
$$

Where $y \_i t$ represents the dependent variable in the model for firm i in t time, y_(it-1) is the lagged dependent variable, $\lambda$ is the adjustment parameter, which is a coefficient value that lies between 0 and 1 , the speed of adjustment is given as (1- $\partial$ ), $\mathrm{X}$ it is the vector of independent variables in the model, $\mu$ (i )is the firm-specific effect, $\mu_{-} t$ is the time effects and the error term is denoted as $\varepsilon_{-}$it. By substituting the study variables into the equation (1), this research specified the following models:

$$
\begin{aligned}
& R O A_{i t}=(\partial-1) R O A_{\mathrm{it}-1}+\beta_{1} B G D_{\mathrm{it}}+\beta_{2} F D_{\mathrm{it}}+\beta_{3} C E O F E_{\mathrm{it}}+\beta_{4} B S_{\mathrm{it}} \\
& +\beta_{5} T D_{\text {it }} \beta_{6} F S_{\text {it }}+\mu_{i}+\mu_{t}+\varepsilon_{i t} \\
& R O E_{i t}=(\partial-1) R O E_{\mathrm{it}-1}+\beta_{1} B G D_{\mathrm{it}}+\beta_{2} F D_{\mathrm{it}}+\beta_{3} C E O F E_{\mathrm{it}}+\beta_{4} B S_{\mathrm{it}} \\
& +\beta_{5} T D_{\text {it }} \beta_{6} F S_{\text {it }}+\mu_{i}+\mu_{t}+\varepsilon_{i t} \\
& R O S_{i t}=(\partial-1) R O S_{\mathrm{it}-1}+\beta_{1} B G D_{\mathrm{it}}+\beta_{2} F D_{\mathrm{it}}+\beta_{3} \text { CEOFE }_{\mathrm{it}}+\beta_{4} B S_{\mathrm{it}} \\
& +\beta_{5} T D_{\text {it }} \beta_{6} F S_{\text {it }}+\mu_{i}+\mu_{t}+\varepsilon_{i t}
\end{aligned}
$$

\begin{tabular}{|c|c|}
\hline $\begin{array}{c}\text { Variable } \\
\text { Dependent Variables: }\end{array}$ & Measurement \\
\hline Return on assets (ROA) & Profits before interest and taxes over total assets \\
\hline Return on equity (ROE) & Profits after taxes over shareholder' capital \\
\hline Return on sales (ROS) & Profits after taxes over sales \\
\hline \multicolumn{2}{|l|}{ Main Explanatory Variables: } \\
\hline Board gender diversity (BGD) & The number of women directors divided by the board size \\
\hline Foreign directors (FD) & $\begin{array}{l}\text { The number of foreign (non-Nigerian) directors divided by the } \\
\text { board size }\end{array}$ \\
\hline CEO financial expertise (CEOFE) & $\begin{array}{l}\text { Dummy variable, if CEO possess a degree in accounting or finance } \\
=1 \text {, otherwise } 0\end{array}$ \\
\hline \multicolumn{2}{|l|}{ Control Variables: } \\
\hline Board size (BS) & The total number of board members \\
\hline Total debt (TD) & Book value of total debt over book value of total assets \\
\hline Firm size (FS) & Firm size, determined as the logarithms of total assets \\
\hline
\end{tabular}

Table 1: Measurement of the Research Variables

\section{RESULTS AND DISCUSSION}

This section presents the empirical results that this study found. The presentation starts with the descriptive analysis, as shown in Table 2, followed by the correlation matrix of the research variables, which is contained in Table 3. Finally, the regression analysis is presented in Table 4. Table 2. provides summary statistics of the research variables. The variable (ROA) represents the ratio of net profit before interest and taxes over total assets, and its mean value is 0.066 . This result suggests that the firms' return 
on assets stood at $6.6 \%$ within the period under review. The firms' financial performance measured by the return on equity (ROE) and return on sales (ROS) shows an average value of $7.9 \%$ and $0.4 \%$, respectively.

Table 2: Descriptive Statistics

\begin{tabular}{lccccccccc}
\hline & ROA & ROE & ROS & BGD & FD & CEOFE & BS & TD & SIZE \\
\hline Mean & 0.066 & 0.079 & 0.004 & 0.139 & 0.181 & 0.257 & 8.495 & 0.236 & 10.127 \\
Std. Dev. & 0.112 & 0.317 & 0.176 & 0.119 & 0.204 & 0.437 & 2.264 & 0.202 & 0.789 \\
Min & -0.207 & -0.779 & -0.368 & 0.000 & 0.000 & 0.000 & 4.000 & 0.000 & 8.378 \\
Max & 0.377 & 0.856 & 0.279 & 0.600 & 0.833 & 1.000 & 17.000 & 0.770 & 11.917 \\
Observations & 553 & 553 & 553 & 553 & 553 & 553 & 553 & 553 & 553 \\
\hline
\end{tabular}

Notes: Table 2 shows the descriptive statistics of the research variables. ROA is the net profit before interest and taxes divided by total assets; ROE is the net profit after tax over shareholders' fund, ROS is the net income over total sales, BGD is the number of women directors over the total number of the board member, FD is the number of foreign directors divided by the total number of board members, CEOFE is a dummy variable $=1$ when a CEO possess a degree in accounting and finance, otherwise $0, B S$ is the total number of board members, TD is the book value of total debt divided by the book value of total assets. SIZE is the logarithms of the total assets.

Given the ROA, ROE, and ROS results, on the average, it seems that the sampled companies are not doing well in terms of financial performance. Moreover, board gender diversity (BGD) and foreign directors (FD) demonstrate that $13.9 \%$ of the board members are female, and $18.1 \%$ represents foreign nationals on the companies' board of directors. Also, the variable CEOFE registers a mean value of 0.257 , suggesting that only $25.7 \%$ of the sampled firms' CEOs have accounting and finance qualification. Overall, these board diversity measures (BGD, FD, and COEFE) indicate that Nigerian listed firms within a period of 2012-2019 have a less diversified board of directors regarding gender, foreign directors, and CEO financial education.

Additionally, the board size (BS) of the sampled firms shows an average of 9 members approximately, with a minimum of 4 members and a maximum of 17 directors. The TD stands as the total debt over total assets, and it exhibits a mean of 0.236. This evidence indicates that the firms' total debt constitutes about $23.6 \%$ of the total capital that the companies employed in financing their operations. The variable firm size (FS), which is measured as the logarithms of the firms' total assets reveals a smaller deviation across the firms, with a minimum and maximum ratio of respectively 8.378 and 11.917 .

Table 3: Correlation Matrix

\begin{tabular}{|c|c|c|c|c|c|c|c|c|c|}
\hline & ROA & ROE & ROS & BGD & FD & CEOFE & $\overline{B S}$ & TD & SIZE \\
\hline ROA & 1.00 & & & & & & & & \\
\hline ROE & $0.51 * * *$ & 1.00 & & & & & & & \\
\hline ROS & $0.73 * * *$ & $0.43 * * *$ & 1.00 & & & & & & \\
\hline BGD & $0.15 * * *$ & $0.09 * *$ & $0.09 * *$ & 1.00 & & & & & \\
\hline FD & $0.21 * * *$ & $0.09 * *$ & $0.18 * * *$ & $-0.21 * * *$ & 1.00 & & & & \\
\hline CEOFE & 0.01 & 0.02 & 0.03 & 0.03 & $-0.19 * * *$ & 1.00 & & & \\
\hline BS & 0.05 & -0.01 & $0.19 * * *$ & -0.05 & $0.22 * * *$ & -0.07 & 1.00 & & \\
\hline TD & $-0.28 * * *$ & $-0.26 * * *$ & $-0.38 * * *$ & -0.02 & 0.02 & 0.03 & -0.10 & 1.00 & \\
\hline SIZE & $0.24 * * *$ & $0.13 * * *$ & $0.25 * * *$ & $0.14 * * *$ & $0.34 * * *$ & -0.05 & $0.43 * *$ & 0.01 & 1.00 \\
\hline
\end{tabular}

$* * *$ and $* *$ indicate $1 \%$, and $5 \%$ level of significance

Notes: ROA is the net profit before interest and taxes divided by total assets. ROE is the net profit after tax over shareholders' fund. BGD is the number of women directors over the total number of board members. FD is the number of foreign directors divided by the total number of board members. CEOFE is a dummy variable $=1$ when a CEO possess a degree in accounting and finance, otherwise O. BS is the total number of board members. TD is the book value of total debt divided by the book value of total assets. SIZE is the logarithms of the total assets.

Furthermore, Table 3 contains the correlation results among the research variables. Based on the results, the correlation coefficient across the explanatory variable is not high. The highest association that the correlation matrix exhibits is between firm size and board size with a coefficient of $43 \%$, which is far 
less than the $80 \%$ threshold that Baltagi (2005) suggested. Hence, the multicollinearity problem does not exist in our model specification.

Table 4: Two-step System GMM Regression Results

\begin{tabular}{|c|c|c|c|}
\hline Variable & $\begin{array}{l}\text { Model } 2 \\
\text { (ROA) }\end{array}$ & $\begin{array}{c}\text { Model 3 } \\
\text { (ROE) }\end{array}$ & $\begin{array}{c}\text { Model } 4 \\
\text { (ROS) }\end{array}$ \\
\hline $\mathrm{ROA}_{\mathrm{it}-1}$ & $\begin{array}{c}0.4150 * * * \\
(0.3334)\end{array}$ & - & - \\
\hline $\mathrm{ROE}_{\mathrm{it}-1}$ & - & $\begin{array}{l}0.3094 * * * \\
(0.0184)\end{array}$ & - \\
\hline $\operatorname{ROS}_{\mathrm{it}-1}$ & - & - & $\begin{array}{c}0.6001 * * * \\
(0.0273)\end{array}$ \\
\hline BGD & $\begin{array}{l}0.0727 * \\
(0.0396)\end{array}$ & $\begin{array}{c}0.0905 \\
(0.0712)\end{array}$ & $\begin{array}{c}0.07335^{* * *} * \\
(0.0258)\end{array}$ \\
\hline FD & $\begin{array}{c}0.0417 * * \\
(0.0195)\end{array}$ & $\begin{array}{l}0.0807 * \\
(0.0417)\end{array}$ & $\begin{array}{c}0.0420 * * * \\
(0.0204)\end{array}$ \\
\hline CEOFE & $\begin{array}{c}0.0020 \\
(0.0083)\end{array}$ & $\begin{array}{c}0.0169 \\
(0.0159)\end{array}$ & $\begin{array}{c}0.0069 \\
(0.0107)\end{array}$ \\
\hline BS & $\begin{array}{c}-0.0034 * * \\
(0.0016)\end{array}$ & $\begin{array}{c}-0.0076^{*} \\
(0.0041)\end{array}$ & $\begin{array}{c}0.0071 \\
(0.0067)\end{array}$ \\
\hline TD & $\begin{array}{c}-0.0787 * * \\
(0.1691)\end{array}$ & $\begin{array}{c}-0.0015^{* *} \\
(0.0061)\end{array}$ & $\begin{array}{c}-0.1123 * * * \\
(0.0204)\end{array}$ \\
\hline SIZE & $\begin{array}{c}0.0155^{* * * *} \\
(0.0038)\end{array}$ & $\begin{array}{c}0.0374 * * * \\
(0.0121)\end{array}$ & $\begin{array}{c}0.0140 * * * \\
(0.0047)\end{array}$ \\
\hline Hansen statistics (P-value) & 0.202 & 0.167 & 0.396 \\
\hline AR1 (P-value) & 0.003 & 0.000 & 0.002 \\
\hline AR2 (P-value) & 0.499 & 0.595 & 0.170 \\
\hline Wald statistics (P-value) & 0.000 & 0.000 & 0.000 \\
\hline Year dummies & Yes & Yes & Yes \\
\hline Industry dummies & Yes & Yes & Yes \\
\hline Number of groups & 70 & 70 & 70 \\
\hline Number of instruments & 40 & 40 & 40 \\
\hline
\end{tabular}

$* * *, * * \& *$ indicate $1 \%, 5 \%$ and $10 \%$ level of significance.

The numbers in parenthesis are standard errors robust to heteroscedasticity.

This table presents the estimates on the relationship between board diversity and financial performance of the 70 Nigerian listed companies. The analysed data covered a period from 2012-2019.

Notes: ROA is the net profit before interest and taxes divided by total assets. ROE is the net profit after tax over shareholders' fund. BGD is the number of women directors over the total number of board members. $F D$ is the number of foreign directors divided by the total number of board members. CEOFE is a dummy variable $=1$ when a CEO possess a degree in accounting and finance, otherwise $0 . B S$ is the total number of board members. TD is the book value of total debt divided by the book value of total assets. SIZE is the logarithms of the total assets.

Table 4 exhibits the two-step system GMM regression results on the effect of board diversity on the financial performance of Nigerian listed firms. According to the results, this study's estimations fulfil the underlying conditions of valid GMM specification. Accordingly, the Hansen statistics' P-value appears insignificant in all the models, indicating that the GMM estimates at hand are robust. Therefore, this article fails to reject the null hypothesis of instruments validity. Likewise, the evidence demonstrates that AR2 exhibits an insignificant P-value in all the models for ROA, ROE, and ROS. This signifies the absence of second-order serial correlation in the models that this research specified. The Wald statistics also reveal the joint significance of the explanatory variables in predicting the firms' financial performance. More importantly, the lagged dependent variables in all the models' specifications show positive and significant $\mathrm{p}$-values at the $1 \%$ level. This finding illustrates that past values of ROA, ROE, 
and ROS are important explanatory variables in estimating the dynamic relationship between board diversity and financial performance of the Nigerian listed companies.

Moreover, based on the regression results, the board gender diversity (BGD) indicates a positive and significant coefficient in its association with ROA and ROS but insignificant with ROE. This strong positive effect implies that the presence of female directors on the boards of the Nigerian listed firms increases the financial performance of the firms measured by ROA and ROS. Thus, reinforcing the argument that gender diversity helps connect firms with social and human capital, enhances their strategic decisions, thus, leading to a higher performance level (Ararat et al., 2015; Dang et al., 2020; Duppati et al., 2020). Therefore, based on this result, the research fails to reject H1. Similarly, the coefficients of the foreign directors (FD) reveal positive and significant impact on firm performance in all the models. This evidence suggests the Nigerian listed firms with a substantial number of foreign nationals are associated with the increased financial performance. Hence, the results align with the predictions of agency and resource dependency theories that boardroom diversity brings new perspective and expertise and thereby shaping firms' performance (Estelyi \& Nisar, 2016; Miletkov et al., 2016; Ujunwa, 2012). Hence, this study fails to reject $\mathrm{H} 2$. On the contrary, the estimated regression results show that CEO financial expertise (CEOFE) demonstrates an insignificant coefficient in all the models that this study specified. This finding suggests CEOs' financial knowledge may not necessarily result in attaining an optimum firm value of the Nigerian listed firms. Thus, demonstrating the importance of other board members acquires financial knowledge for the firms to operate at an optimum financial performance level. Hence, this paper rejects $\mathrm{H} 3$. Instead, this empirical evidence reinforces the proposition of upper-echelons theory that the managers' collective cognitive powers and experiences more often results in better organisational outcomes (Hambrick, 2007; Hambrick, and Mason, 1984).

Furthermore, the control variables that this study employed display signs consistent with the existing studies. The variable board size (BS) shows a negative and significant relationship with ROA and ROE respectively at 5\% and $10 \%$. This finding implies larger board size reduces the performance of the Nigerian listed firms. This empirical evidence supports the argument that oversize boards suffer from poor coordination, conflicts, and disagreements among board members, which in turn, leading to poor performance (Pillai \& Al-Malkawi, 2018; Yermack, 1996). Also, the firms' leverage ratio (TD) exhibits a negative and significant effect on specification of all the models. This strong estimated negative effect is consistent with Shyam-Sunder and Myers (1999) and Sheikh and Wang (2013). These studies reported that profitable firms have less preference for debt capital and thus leverage decreases, as firms' profitability rises. Lastly, the firm size shows positive and significant coefficient in predicting ROA, ROE, and ROS. The results demonstrate the relevance of larger size in explaining the profitability variation of the sampled firms. This empirical result agrees with the literature emphasising that economies of scale advantage accrue to larger firms, resulting in a lower production cost and eventually improving financial performance (Altaf \& Shah, 2018; Muniandy \& Hillier, 2015).

\section{CONCLUSION}

This paper examined the impact of board diversity on financial performance of the Nigerian listed firms. The study utilised the balanced panel data of 70 firms in a period of 2012-2019 using a generalised method of moments (GMM) framework. The article viewed the nexus between boardroom diversity and firms' financial performance within the context of the agency theory, resource dependency, and upperechelons perspectives. The study found that board gender diversity and foreign directors have a positive and significant impact on financial performance. Thus, the evidence underscores the relevance board diversity in predicting the Nigerian listed companies' optimum performance level. The paper also showed that board size, leverage, and firm size might also explain the variation of profitability across the Nigerian firms. More importantly, the findings from this research have some policy implications on enhancing the firms' performance level. Firstly, the Nigerian listed firms should focus on constituting a smaller board size with a considerable number of female and foreign directors to maximise their value. Likewise, as shown by the results in this study, CEO financial expertise alone may not necessarily lead to optimising firm value. Therefore, it is imperative for the sampled companies to employ a higher number of board 
members with financial expertise to maximise financial performance. Although this paper provides further insights on corporate governance literature, yet it has some limitations. The research covered only three aspects of board diversity measures. Therefore, future studies should explore other proxies for measuring board diversity to provide more evidence on the determinants of firms' financial performance.

\section{REFERENCES}

Abdullah, S. N. (2014). The Causes of Gender Diversity in Malaysian Large Firms. Journal of Management and Governance, 18, 1137-1159. https://doi.org/10.1007/s10997-013-9279-0

Adams, R. B., \& Ferreira, D. (2009). Women in the Boardroom and Their Impact on Governance and Performance. Journal of Financial Economics, 94(2), 291-309. https://doi.org/10.1016/j.jfineco.2008.10.007

Altaf, N., \& Shah, F. A. (2018). Ownership Concentration and Firm Performance in Indian Firms: Does Investor Protection Quality Matter? Journal of Indian Business Research, 10(1), 33-52. https://doi.org/10.1108/jibr-01-2017-0009

Ararat, M., Aksu, M., \& Cetin, A. T. (2015). How Board Diversity Affects Firm Performance in Emerging Markets: Evidence on Channels in Controlled Firms. Corporate Governance: An International Review, 23(2), 83-103. https://doi.org/10.1111/corg.12103

Arellano, M., \& Bond, S. (1991). Some Tests of Specification for Panel Data: Monte Carlo Evidence and An Application to Employment Equations. The Review of Economic Studies, 58(2), 277-297. https://doi.org/10.2307/2297968

Arellano, M., \& Bover, O. (1995). Another Look at the Instrumental Variable Estimation of ErrorComponents Models. Journal of Econometrics, 68, 29-51. https://doi.org/10.1016/03044076(94)01642-d

Baltagi, B. H. (2005). Econometric Analysis of Panel Data (Third Edition). West Sussex, England: John Wiley \& Sons, Ltd.

Bart, C., \& McQueen, G. (2013). Why Women Make Better Directors. International Journal of Business Governance and Ethics, 8(1), 93-99. https://doi.org/10.1504/ijbge.2013.052743

Blundell, R., \& Bond, S. (1998). Initial Conditions and Moment Restrictions in Dynamic Panel Data Models. Journal of Econometrics, 87, 115-143. https://doi.org/10.1016/s0304-4076(98)00009-8

Bun, M. J. G., \& Windmeijer, F. (2010). The Weak Instrument Problem of the System GMM Estimator in Dynamic Panel Data Models. The Econometrics Journal, 13(1), 95-126. https://doi.org/10.1111/j.1368-423x.2009.00299.x

Custodio, C., \& Metzger, D. (2014). Financial Expert CEOs: CEO's Work Experience and Firm's Financial Policies. Journal of Financial Economics, 114, 125-154. https://doi.org/10.1016/j.jfineco.2014.06.002

Dang, R., Houanti, L., Reddy, K., \& Simioni, M. (2020). Does Board Gender Diversity Influence Firm Profitability? A Control Function Approach. Economic Modelling, 90, 168-181. https://doi.org/10.1016/j.econmod.2020.05.009

Darmadi, S. (2013). Board Members' Education and Firm Performance: Evidence from a Developing Economy. International Journal of Commerce and Management, 23(2), 113-135. https://doi.org/10.1108/10569211311324911

Duppati, G., Rao, N. V., Matlani, N., Scrimgeour, F., \& Patnaik, D. (2020). Gender Diversity and Firm Performance: Evidence from India and Singapore. Applied Economics, 52(14), 1553-1565. https://doi.org/10.1080/00036846.2019.1676872 
Estelyi, K. S., \& Nisar, T. M. (2016). Diverse Boards: Why Do Firms Get Foreign Nationals on their Boards? Journal of Corporate Finance, 39, 174-192. https://doi.org/10.1016/j.jcorpfin.2016.02.006

Fama, E. F., \& Jensen, M. C. (1983). Separation of Ownership and Control. Journal of Law and Economics, 26(2), 301-325. https://doi.org/10.1086/467037

Fernandez-Temprano, M. A., \& Tejerina-Gaite, F. (2020). Types of Director, Board Diversity and Firm Performance. Corporate Governance (Bingley), 20(2), 324-342. https://doi.org/10.1108/cg-032019-0096

Gillan, S. L. (2006). Recent Developments in Corporate Governance: An Overview. Journal of Corporate Finance, 12(3), 381-402. https://doi.org/10.1016/j.jcorpfin.2005.11.002

Graham, J. R., \& Harvey, C. R. (2001). The Theory and Practice of Corporate Finance: Evidence from the Field. Journal of Financial Economics, 60, 187-243. https://doi.org/10.1016/s0304-405x(01)000447

Gujarati, D. N. (2003). Basic Econometrics (Fourth Edition). New York: McGraw-Hill Higher Education.

Guner, A. B., Malmendier, U., \& Tate, G. (2008). Financial Expertise of Directors. Journal of Financial Economics, 88(2), 323-354. https://doi.org/10.1016/j.jfineco.2007.05.009

Hackbarth, D. (2008). Managerial Traits and Capital Structure Decisions. Journal of Financial and Quantitative Analysis, 43(4), 843-881. https://doi.org/10.1017/s002210900001437x

Hambrick, D. C. (2007). Upper Echelons Theory: An Update. Academy of Management, 32(2), 334-343. https://doi.org/10.5465/amr.2007.24345254

Hambrick, D. C., \& Mason, P. A. (1984). Upper Echelons: The Organisation as a Reflection of its Top Managers. The Academy of Management, 9(2), 193-206. https://doi.org/10.5465/amr.1984.4277628

Hillman, A. J., Cannella, A. A., \& Paetzold, R. L. (2000). The Resource Dependence Role of Corporate Directors: Strategic Adaptation of Board Composition in Response to Environmental Change. Journal of Management Studies, 37(2), 235-256. https://doi.org/10.1111/1467-6486.00179

Hillman, A. J., \& Dalziel, T. (2003). Boards of Directors and Firm Performance: Integrating Agency and Resource Dependence Perspectives. The Academy of Management Review, 28(3), 383-396. https://doi.org/10.5465/amr.2003.10196729

Iamsiraroj, S. (2016). The Foreign Direct Investment-Economic Growth Nexus. International Review of Economics and Finance, 42, 116-133. https://doi.org/10.1016/j.iref.2015.10.044

Ilaboya, J., \& Ashafoke, T. (2017). Board Diversity and Firm Performance in Nigeria. International Journal of Management, Accounting and Economics, 4(10), 1002-1019.

Jensen, M. C. (1986). Agency Costs of Free Cash Flow, Corporate Finance and Takeovers. The American Economic Review, 76(2), 323-329. https://doi.org/10.1017/cbo9780511609435.005

Jensen, M. C. (1993). The Modern Industrial Revolution, Exit, and the Failure of Internal Control Systems. The Journal of Finance, 48(3), 831-880. https://doi.org/10.1111/j.15406261.1993.tb04022.x

Jensen, M. C., \& Meckling, W. H. (1976). Theory of the Firm: Managerial Behavior, Agency Costs and Ownership Structure. Journal of Financial Economics, 3(4), 305-360. https://doi.org/10.1016/0304-405x(76)90026-x

Jeon, J. Q., \& Ryoo, J. (2013). How do Foreign Investors Affect Corporate Policy?: Evidence from Korea. International Review of Economics and Finance, 25, 52-65. https://doi.org/10.1016/j.iref.2012.05.001 
Kilic, M., \& Kuzey, C. (2016). The Effect of Board Gender Diversity on Firm Performance: Evidence from Turkey. Gender in Management, 31(7), 434-455. https://doi.org/10.1108/gm-10-2015-0088

Li, Y., \& Zhang, X. Y. (2019). Impact of Board Gender Composition on Corporate Debt Maturity Structures. European Financial Management, 25(5), 1286-1320. https://doi.org/10.1111/eufm.12214

Masulis, R. W., Wang, C., \& Xie, F. (2012). Globalising the Boardroom-The Effects of Foreign Directors on Corporate Governance and Firm Performance. Journal of Accounting and Economics, 53(3), 527-554. https://doi.org/10.1016/j.jacceco.2011.12.003

Miletkov, M., Poulsen, A., \& Wintoki, M. B. (2016). Foreign Independent Directors and the Quality of Legal Institutions. Journal of International Business Studies, 48(2), 267-292. https://doi.org/10.1057/s41267-016-0033-0

Min, B. S., \& Chizema, A. (2015). Board Meeting Attendance by Outside Directors. Journal of Business Ethics, 147(4), 901-917. https://doi.org/10.1007/s10551-015-2990-9

Minguez-Vera, A., \& Martin, A. (2011). Gender and Management on Spanish SMEs: An Empirical Analysis. International Journal of Human Resource Management, 22(14), 2852-2873. https://doi.org/10.1080/09585192.2011.599948

Mottaleb, K. A., \& Kalirajan, K. (2010). Determinants of Foreign Direct Investment in Developing Countries. The Journal of Applied Economic Research, 4(4), 369-404. https://doi.org/10.1177/097380101000400401

Muniandy, B., \& Hillier, J. (2015). Board Independence, Investment Opportunity Set and Performance of South African Firms. Pacific-Basin Finance Journal, 35, 108-124. https://doi.org/10.1016/j.pacfin.2014.11.003

Nadeem, M. (2020). Does Board Gender Diversity Influence Voluntary Disclosure of Intellectual Capital in Initial Public Offering Prospectuses? Evidence from China. Corporate Governance: An International Review, 28(2), 100-118. https://doi.org/10.1111/corg.12304

Naseem, M. A., Lin, J., Rehman, R., Ahmad, M. I., \& Ali, R. (2019). Does Capital Structure Mediate the Link Between CEO Characteristics and Firm Performance? Management Decision, 58(1), 164-181. https://doi.org/10.1108/md-05-2018-0594

Ozkan, A. (2001). Determinants of Capital Structure and Adjustment to Long Run Target: Evidence from UK Company Panel Data. Journal of Business Finance and Accounting, 28(2), 175-198. https://doi.org/10.1111/1468-5957.00370

Pfeffer, J. (1973). Size, Composition, and Function of Hospital Boards of Directors : A Study of Organization- Environment Linkage. Administrative Science Quarterly, 18(3), 349-364. https://doi.org/10.2307/2391668

Pfeffer, J., \& Salancik, G. R. (2003). The External Control of Organisations: A Resource Dependence Approach. California: Standford University Press.

Pillai, R., \& Al-Malkawi, H. A. N. (2018). On the Relationship Between Corporate Governance and Firm Performance: Evidence from GCC Countries. Research in International Business and Finance, 44, 394-410. https://doi.org/10.1016/j.ribaf.2017.07.110

Roodman, D. (2009). How to do Xtabond2: An Introduction to Difference and System GMM in Stata. The Stata Journal, 9(1), 86-136. https://doi.org/10.1177/1536867x0900900106

Sani, A. (2020). Managerial Ownership and Financial Performance of the Nigerian Listed Firms: The Moderating Role of Board Independence. International Journal of Academic Research in 
Accounting, Finance and Management Sciences, 10(3), 64-73. http://dx.doi.org/10.6007/ijarafms/v10-i3/7821

Sheikh, N. A., \& Wang, Z. (2013). The Impact of Capital Structure on Performance: An Empirical Study of Non-Financial Listed Firms in Pakistan. International Journal of Commerce and Management, 23(4), 354-368. https://doi.org/10.1108/ijcoma-11-2011-0034

Shyam-Sunder, L., \& Myers, S. C. (1999). Testing Static Tradeoff Against Pecking Order Models of Capital structure. Journal of Financial Economics, 51(2), 219-244. https://doi.org/10.3386/w4722

Singh, V. (2007). Ethnic Diversity on Top Corporate Boards: A Resource Dependency Perspective. The International Journal of Human Resource Management, 18(12), 2128-2146. https://doi.org/10.1080/09585190701695275

Singh, V., Terjesen, S., \& Vinnicombe, S. (2008). Newly Appointed Directors in the Boardroom: How Do Women and Men Differ? European Management Journal, 26, 48-58. https://doi.org/10.1016/j.emj.2007.10.002

Ujunwa, A. (2012). Board Characteristics and the Financial Performance of Nigerian Quoted Firms. Corporate Governance (Bingley), 12(5), 656-674. https://doi.org/10.1108/14720701211275587

Vitolla, F., Raimo, N., \& Rubino, M. (2020). Board Characteristics and Integrated Reporting Quality: An Agency Theory Perspective. Corporate Social Responsibility and Environmental Management, 27(2), 1152-1163. https://doi.org/10.1002/csr.1879

Wintoki, M. B., Linck, J. S., \& Netter, J. M. (2012). Endogeneity and the Dynamics of Internal Corporate Governance. Journal of Financial Economics, 105(3), 581-606. https://doi.org/10.1016/j.jfineco.2012.03.005

World Bank (2020). GDP estimates in Sub-Saharan Africa. https://data.worldbank.org/?locations=ZG-NG / accessed on 18th November 2020.

Yermack, D. (1996). Higher Market Valuation for Firms with a Small Board of Directors. Journal of Financial Economics, 40, 185-211. https://doi.org/10.1016/0304-405x(95)00844-5

Zahra, S. A., \& Pearce, J. A. (1989). Boards of Directors and Corporate Financial Performance: A Review and Integrative Model. Journal of Management, 15(2), 291-334. https://doi.org/10.1177/014920638901500208 